\title{
Serum standards for the bioassay of aminoglycosides in cerebrospinal fluid
}

\author{
S. HAMMERBERG, R. SINAI, AND M. I. MARKS ${ }^{1}$ \\ From the Departments of Pediatrics (Infectious Diseases) and Microbiology, McGill University- \\ Montreal Children's Hospital Research Institute, Montreal, PQ, Canada
}

SUMMARY Four diluents were compared as reference standards for the assay of gentamicin in cerebrospinal fluid (CSF): human CSF, human serum, distilled water, and $150 \mathrm{mmol} \mathrm{NaCl} / 4 \cdot 5_{\vec{i}}$ $\mathrm{mmol} \mathrm{CaCl} \mathrm{Cl}_{2}$. Standards prepared in pooled human serum were the best alternative to CSF for the $\vec{\sim}$ assay of gentamicin and were also useful for the assay of tobramycin, netilmicin, amikacin, and $N$ sisomicin. The pH (6.0-9.8) of CSF did not alter the results of the assay.

The accurate determination of microbiologically active gentamicin in cerebrospinal fluid(CSF) is often critical in the management of patients with Gramnegative bacterial meningitis. Several clinical studies have reported CSF drug concentrations; however, standards for the assay were not specified (Kaiser and McGee, 1971; McCracken, 1972; McCracken and Mize, 1976). Although CSF would seem to be the best diluent for standards, it is often not available. A recent report described an alternative solution for CSF standards (Deacon, 1976a). We compared this artificial diluent $(150 \mathrm{mmol} \mathrm{NaCl} / 4.5 \mathrm{mmol}$ $\mathrm{CaCl}_{2}$ ) with distilled water, human $\mathrm{CSF}$, and pooled human serum. Since cerebrospinal fluid $\mathrm{pH}$ may vary markedly, the effect of $\mathrm{pH}$ was also examined. Unlike Deacon's report, our results indicate that CSF or serum is a better diluent for gentamicin standards than the artificial solution or water. Serum was found to be a reliable alternative to CSF for four newer aminoglycosides as well.

\section{Material and methods}

Microbiologically active gentamicin was measured by the Bennett agar diffusion assay method using a serum-resistant gentamicin-sensitive Klebsiella pneumoniae as the test organism (Bennett et al., 1966). Bacto antibiotic medium 11 (Difco) was substituted

'Reprint requests: Dr M. I. Marks, Montreal Children's Hospital, 2300 Tupper Street, Montreal, PQ H3H 1P3, Canada

Received for publication 27 July 1977 for nutrient agar as the former produced clearer $\frac{C}{d}$ zones of inhibition. A $30-\mathrm{mm}$ square agar plate was flooded with a $1 / 100$ dilution of an overnight growth $\vec{\varphi}$ of the test organism in nutrient broth. The excess $\underset{\infty}{-}$ inoculum was removed by pipette and the plate was dried by incubation for approximately 45 minutes at $37^{\circ} \mathrm{C}$ with the lid ajar. Wells ( $2 \mathrm{~mm}$ diameter) were cut in the seeded plate and numbered so that samples

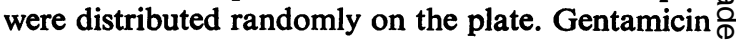
standards were prepared in concentrations of $20,10, \underline{a}$ $5,2 \cdot 5$, and $1 \cdot 25 \mu \mathrm{g} / \mathrm{ml}$ in the various test fluids. Four $\overline{0}$ replications of each sample were performed for each 3 of three tests, and zones of inhibition (mm) were recorded and averaged after 18-20 hours' incubation. Standard curves were plotted on semilog paper. The same method was employed when four other amino-: glycosides were assayed to compare CSF and serum 3 as diluents.

CSF was obtained from hospital patients without leptomeningitis or ventriculitis. CSF 1 was from ao hydrocephalic patient; CSF 2, 3, and 4 were CSF pools obtained from diagnostic lumbar puncture in febrile infants without meningitis. Human serum was collected from adult volunteers. Glucose, protein, $\widetilde{N}$ and cell count of the CSF were determined by $N$ standard methods. CSF 1, 2, and 3 and different pools of human serum were used for each of three experiments involving gentamicin (Table 1). The $\mathrm{NaCl} / \mathrm{CaCl}_{2}$ solution was prepared as recommended by Deacon (1976a).

The effect of $\mathrm{pH}$ was examined with CSF 4. Using $2 \% \mathrm{HCl}$ and $4 \% \mathrm{NaOH}$ the samples were adjusted $\bar{O}$ to $\mathrm{pH} 6,7,8 \cdot 2,9$, and 9.8. Gentamicin was added to each sample to yield a final concentration of $5 \mu \mathrm{g} / \mathrm{ml}$. $\frac{\rho}{\mathbb{Q}}$ 
Table 1 Analyses of four cerebrospinal fluids

\begin{tabular}{lllll}
\hline & CSF 1 & CSF 2 & CSF 3 & CSF 4 \\
\hline Glucose (mg/100 ml) & 39 & 64 & 64 & 47 \\
$(\mathrm{mmol} / \mathrm{l})$ & $2 \cdot 2$ & 3.6 & 3.6 & 2.6 \\
Protein $(\mathrm{g} / \mathrm{l})$ & 0.72 & 0.14 & 0.09 & 0.38 \\
Cell count/mm & 53 polys & 0 polys & 0 polys & 1 poly \\
& 21 lymphs & 1 lymph & 1 lymph & 0 lymph \\
\hline
\end{tabular}

\section{Results}

The average of the results of the standard curves of three experiments with gentamicin diluted in Deacon's solution, distilled water, and pooled human serum is compared to that obtained with pooled human CSF (Figure). The mean difference in zones of inhibition (CSF-alternative diluent) for gentamicin diluted in distilled water when compared to CSF was $1.65 \mathrm{~mm}$ (range 1.0 to $+2.25 \mathrm{~mm}$ ), for Deacon's solution $1 \mathrm{~mm}$ (range 0.75 to $+1.75 \mathrm{~mm}$ ), and for serum $0.05 \mathrm{~mm}$ (range 0 to $+0.25 \mathrm{~mm}$ ). The most accurate approximation of the CSF curve was obtained with standards prepared in pooled human serum (Figure). The zones of inhibition were in exact agreement for one run (CSF 1) and insignificantly different (mean differences CSF-serum +0.35 , $-0.35 \mathrm{~mm}$ ) in two other runs using different CSF and serum pools. Pooled human CSF standards of 5 $\mu \mathrm{g} / \mathrm{ml}$ gentamicin with a $\mathrm{pH}$ of $6,7,8.2,9$, and $9 \cdot 8$ gave identical zone sizes. Newer aminoglycosides were assayed to compare standards prepared in CSF

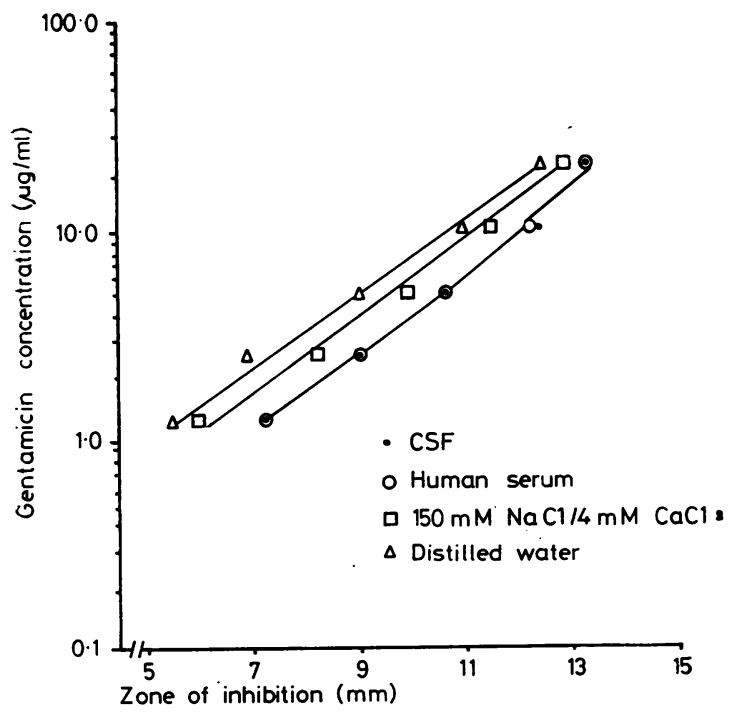

Figure Comparison of average zones of inhibition of various gentamicin concentrations prepared in four diluents and serum. The results of a single experiment with four replications are listed in Table 2 and demonstrate negligible differences in zone diameters between the standards.

Table 2 Difference in zones of inhibition between standards prepared in CSF and serum

\begin{tabular}{llr}
\hline Antibiotic & \multicolumn{2}{l}{ CSF-serum $(\mathrm{mm})$} \\
\cline { 2 - 3 } & Mean difference & Range \\
\hline Tobramycin & 0.25 & 0 to +1.0 \\
Netilmicin & 0.24 & 0 to +0.6 \\
Amikacin & 0.21 & -0.3 to +0.5 \\
Sisomicin & 0.22 & -0.2 to +0.8 \\
\hline
\end{tabular}

\section{Discussion}

The activity of gentamicin in serum is subject to various physiological conditions, that is, effect of $\mathrm{pH}$, ionic strength, protein, serum, etc. (Rubenis et al., 1963; Deacon, 1976b; Shanson and Daniels, 1975). We found no report comparing gentamicin activity in pooled human serum and CSF. It would be technically convenient to be able to assay both serum and CSF gentamicin concentrations using one set of reference standards. The results of our studies indicate that this is valid for gentamicin as well as for four newer aminoglycosides and that the use of distilled water or electrolyte solutions may lead to considerable inaccuracies. The reasons for the lack of agreement of our results with those of Deacon (1976a) are unclear. Technical differences such as the use of a single assay plate for all samples in our study versus the use of several separate plates by Deacon (1976a) may be responsible. Shanson and Daniels (1975) reported that ionic content affected serum standards when the $\mathrm{pH}$ was altered from $7 \cdot 5$ to $6 \cdot 7$. On testing this phenomenon by comparing serum and CSF standards at pH 6.4, 8, and 9.3, no effect was demonstrable. This difference in results is probably due to the extreme sensitivity of Shanson and Daniels' assay organism and the use of 7-mm rather than $2-\mathrm{mm}$ wells. The advantages in sensitivity offered by their method may be outweighed by the inaccuracies incurred through the use of separate plates for each sample. In conclusion, using the assay method described in this study, drug standards prepared in pooled human serum are reliable for the microbiological assay of CSF gentamicin concentrations as well as those of tobramycin, sisomicin, amikacin, and netilmicin.

\section{References}

Bennett, J. V., Brodie, J. L., Benner, E. J., and Kirby, W. M. M. (1966). Simplified accurate method for anti- 
biotic assay of clinical specimens. Applied Microbiology, 14, 170-177.

Deacon, S. (1976a). Assay of gentamicin in cerebrospinal fluid. Journal of Clinical Pathology, 29, 749-751.

Deacon, S. (1976b). Factors affecting the assay of gentamicin by the plate diffusion method. Journal of Clinical Pathology, 29, 54-57.

Kaiser, A. B., and McGee, Z. A. (1971). Aminoglycoside therapy of Gram-negative bacillary meningitis. New England Journal of Medicine, 293, 1215-1220.

McCracken, G. H., Jr. (1972). The rate of bacteriologic response to antimicrobial therapy in neonatal menin- gitis. American Journal of Diseases of Children, 123, 547-553.

McCracken, G. H., Jr, and Mize, S. G. (1976). A controlled study of intrathecal antibiotic therapy in Gram $-?$ negative enteric meningitis of infancy. Journal of Pediatrics, 89, 66-72.

Rubenis, M., Kozij, V. M., and Jackson, G. G. (1963). $\frac{\bar{D}}{\bar{Q}}$ Laboratory studies on gentamicin. Antimicrobial $\mathbb{D}_{\Omega}$ Agents and Chemotherapy, 3, 153-156.

Shanson, D. C., and Daniels, J. V. (1975). Factors ${ }^{(1)}$ affecting plate assay of gentimicin I. Diluents. Journalo of Antimicrobial Chemotherapy, 1, 219-227.

\section{The January 1978 issue}

\section{THE JANUARY 1978 ISSUE CONTAINS THE FOLLOWING PAPERS}

Use of cell cultures as an indicator of pathogenicity of free-living amoebae RAY T. M. CURSONS AND TIM J. BROWN

Specific and non-specific resistance to aminoglycosides in Escherichia coli S. L. MAWER AND D. GREENWOOD

Evaluation and application of an improved bacteriocin typing method for Klebsiella aerogenes G. W. HEDDELL AND A. A. B. MITCHELL

Identification of Enterobacteriaceae by the API $20 \mathrm{E}$ system B. HOLMES, W. R. WILLCOX, AND S. P. LAPAGE

Detection of capsulated Haemophilus influenzae in chest infections by counter current immunoelectrophoresis MICHELE MCINTYRE

An assessment of radial haemolysis in the detection of rubella antibody B. GEE, BARBARA E. JORDAN, AND P. R. MORTIMER

Complex nature of serum lysozyme activity: evidence of thermolability in inflammatory bowel disease $M$. WARD, W. D. MITCHELL, AND M. EASTWOOD

Early detection of folic acid deficiency in elderly patients C. G. L. RAPER AND M. CHOUDHURY

Measurement of red cell folate with ${ }^{75}$ Se-selenofolate radioassay IAN JOHNSON AND MICHAEL ROSE
A whole blood control for the Coulter Model S: L. O. MORGAN, W. G. JONES, J. FISHER, AND I. CAVILL ฏ A rapid screening test for reduced fibrinolytic $\vec{\varphi}$ activity of plasma: streptokinase activated lysis time $\infty$ E. GIDRON, R. MARGALIT, AND Y. SHALITIN

Serum bile acids in patients with hyperlipidaemia C. R. PENNINGTON, P. E. ROSS, M. C. BATESON, AND IAN A. D. BOUCHIER

Cross contamination of cytological smears with automated staining machines and bulk manual staining procedures O. A. N. HUSAIN, J. M. GRAINGER, AND J. SIMS

Gastric and duodenal mucosa in 'healthy' individuals J. KREUNING, F. T. BOSMAN, G. KUIPER, A. M. v.d. WAL, AND J. LINDEMAN

Idiopathic fibrosis of mediastinum: a discussion of three cases and review of the literature A. M. LIGHT Dysfibrinogenaemia and liver cell growth R. D. BARR, MARY ALLARDYCE, P. W. BRUNT, AND J. L. N MCPHIE

\section{Technical method}

A new automated uric acid assay A. C. PAREKH, C. SIMS, AND R. W. FONG

Letters to the Editor

Book reviews

Copies are still available and may be obtained from the PUBLISHING MANAGER, BRITISH MEDICAL ASSOCIATION, TAVISTOCK SQUARE, LONDON, WC1H 9JR, price $£ 3.00$, including postage 